\title{
Three species of Magnibursatus Naidenova, 1969 (Digenea: Derogenidae) from Atlantic and Black Sea marine teleosts
}

\author{
Aneta Kostadinova ${ }^{1,2}$, Anne Marie Power ${ }^{2}$, Mercedes Fernández ${ }^{2}$, Juan Antonio Balbuena ${ }^{2}$, Juan Antonio \\ Raga $^{2}$ and David I. Gibson ${ }^{3}$
${ }^{1}$ Department of Biodiversity, Central Laboratory of General Ecology, Bulgarian Academy of Sciences, 2 Gagarin Street, 1113 Sofia, Bulgaria; 46071 Valencia, Spain;
${ }^{3}$ Department of Zoology, The Natural History Museum, Cromwell Road, London, SW7 5BD, UK \\ ${ }^{2}$ Marine Zoology Unit, Cavanilles Institute of Biodiversity and Evolutionary Biology, University of Valencia, P.O. Box 22 085,
}

Key words: Digenea, Magnibursatus, key to species, marine fish

\begin{abstract}
Three species of Magnibursatus Naidenova, 1969 are described from marine teleosts: M. skrjabini (Vlasenko, 1931), the type species of the genus, from the gobiid Zosterisessor ophiocephalus on the Bulgarian Black Sea coast; M. bartolii sp. $\mathrm{n}$. from the sparid Boops boops off the Atlantic coast of Spain; and M. minutus sp. n. from the gobiid Neogobius eurycephalus on the Bulgarian Black Sea coast. M. bartolii differs from all other Magnibursatus species in its larger sinus-sac (length $>250 \mu \mathrm{m}$, width $>150 \mu \mathrm{m})$ and the more posterior location of testes. This species is also unusual in that it occurs in the branchial chamber and on the gills of its host. M. minutus is distinguished by the distinctly smaller dimensions of the body (length $<1000 \mu \mathrm{m}$, width $<200 \mu \mathrm{m}$ ), organs and eggs. These species are also distinguished from both M. caudofilamentosa (Reimer, 1971) and Tyrrhenia blennii Paggi et Orecchia, 1975. A key to the species of Magnibursatus is presented.
\end{abstract}

During a survey of parasites of bogue, Boops boops (L.), off the Atlantic coasts of Spain, we came across a species possessing characteristics of two halipegine derogenid genera, Magnibursatus Naidenova, 1969 and Tyrrhenia Paggi et Orecchia, 1975. In attempting to identify the specimens we have examined comparative material (27 specimens) from Black Sea gobiid fishes provisionally identified as Magnibursatus skrjabini (Vlasenko, 1931) Naidenova, 1969 by Dr. G. Dimitrov (Bulgarian Academy of Sciences). We have found that the Atlantic form and part of the Black Sea material both show some distinctive features, which led us to describe them as new species. This paper includes a redescription of $M$. skrjabini and descriptions of two new species of Magnibursatus, one collected from $B$. boops off the Northern Atlantic coasts of Spain and the other from Black Sea gobiids.

\section{MATERIALS AND METHODS}

The trematodes from B. boops were dissected out from freshly frozen fish, fixed in alcohol-formol-acetic acid (AFA), transferred to $70 \%$ ethanol, stained with iron acetocarmine (Georgiev et al. 1986) and mounted in Canada balsam. Specimens from Black Sea fishes were dissected out from freshly caught fish, killed in a hot normal saline solution, transferred to $70 \%$ ethanol, stained and mounted as above. The type and voucher material is deposited at The Natural History Museum, London $[\mathrm{BM}(\mathrm{NH})]$ and in the collections of both the Central Laboratory of General Ecology, Bulgarian Academy of Sciences (CLGE) and the Cavanilles Institute of Biodiversity and Evolutionary Biology, University of Valencia (ICBIBE).

The following abbreviations for ratios (expressed as percentages) are used in the text and table: FO/BL, forebody length as a proportion of body length; PT/BL, post-testicular field length as a proportion of body length; AT/BL, distance from ventral sucker to anterior testis as a proportion of body length; and $\mathrm{OV} / \mathrm{BL}$, post-ovarian field length as a proportion of body length. Measurements and scales are in micrometres.

\section{RESULTS}

Family D e r o g e n i d a e Nicoll, 1910

Subfamily H a li p e g i n a e Poche, 1926

MAGNIBURSATUS Naidenova, 1969

Magnibursatus skrjabini (Vlasenko, 1931)

Fig. 1A, B, D

Redescription. Based on 12 whole-mounts. Measurements (see Table 1) taken from 10 adults. Body elongate, widest at level of ventral sucker or testes. Tegument thick, unarmed. Pre-oral lobe present. Oral sucker subterminal, spherical. Ventral sucker muscular, distinctly larger than oral sucker, cup-shaped, slightly protuberant. Forebody relatively long. Prepharynx absent. Pharynx subglobular. Oesophagus short. Intestinal bifurcation just posterior to pharynx. 'Drüsenmagen' present. Caeca with thick epithelial lining, end blindly fairly close to posterior end of body. 


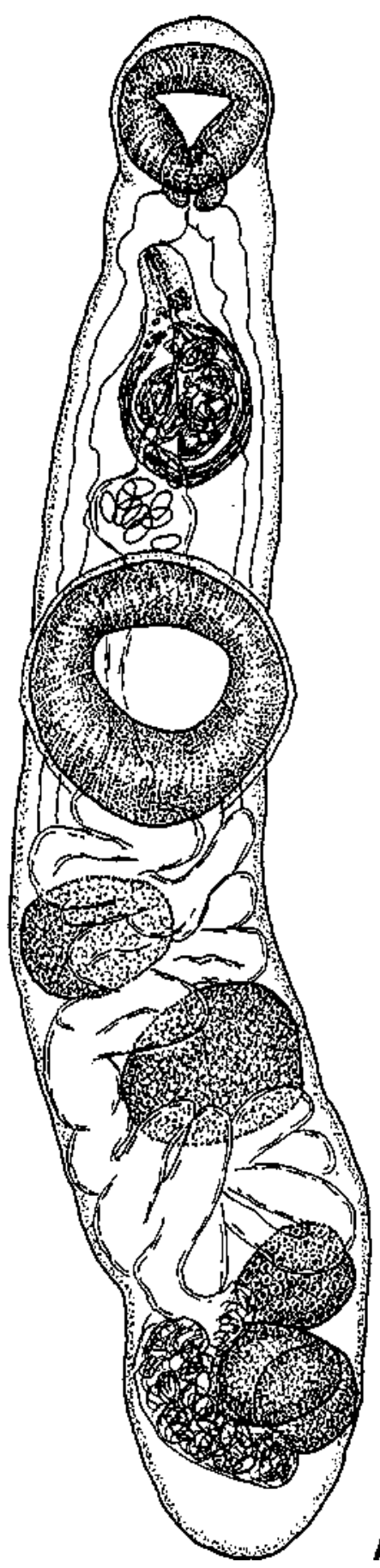

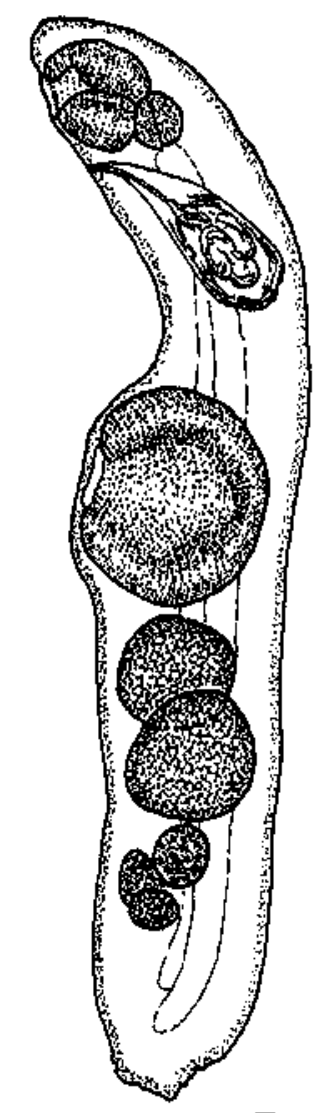

B
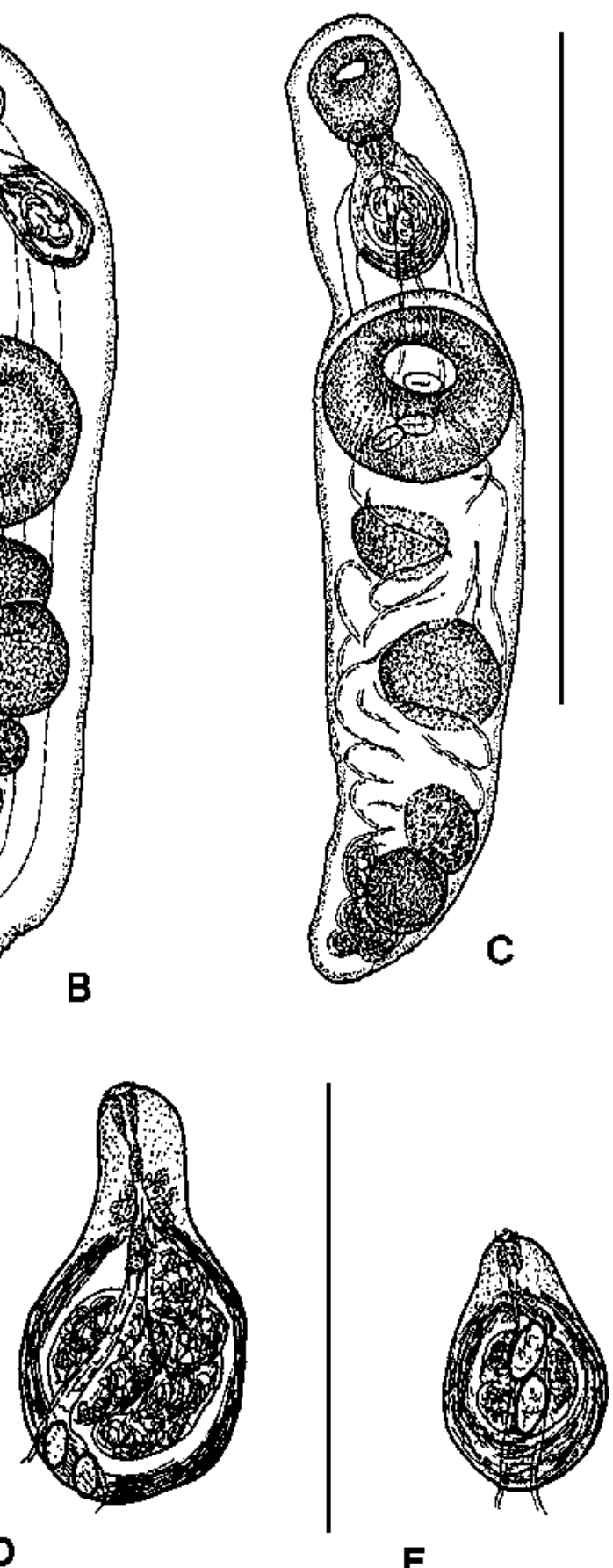

$\mathbf{E}$

Fig. 1. Magnibursatus spp. A - M. skrjabini (Vlasenko, 1931) ex Zosterisessor ophiocephalus, mature adult, ventral view; B M. skrjabini, immature specimen, lateral view; C - M. minutus sp. n. ex Neogobius eurycephalus, holotype, ventral view; D - M. skrjabini, terminal genitalia; $\mathbf{E}-$ M. minutus, terminal genitalia. Scale bars: A, B, C = 500 $\mu \mathrm{m} ; \mathrm{D}, \mathrm{E}=200 \mu \mathrm{m}$.

Testes 2, oval, entire, oblique, fairly close to each other or contiguous. Anterior testis always dextral, adjacent to posterior border of ventral sucker or separated from it by uterine coil; posterior testis sinistral, in mid-hindbody. Seminal vesicle elongate, tubular, c. 30 wide, coiled. Pars prostatica short; prostatic cells large. Hermaphroditic duct short. Sinus- sac large, broadly oval, comparable in size to oral sucker, in middle of forebody; its posterior $2 / 3$ with multi-layered muscular wall up to 13-20 thick; male and female ducts unite within proximal thin-walled portion. Genital atrium shallow. Permanent sinus organ not observed. Genital pore median, at level of pharynx or slightly posterior. 
Ovary sinistral, distinctly smaller than testes, transversely-oval, usually well separated from posterior testis. Laurer's canal and rudimentary seminal receptacle not seen. Uterine seminal receptacle well developed, coils from level of ovary to near posterior end of body, filled with spermatozoa and some eggs. Uterus fills much of hindbody, passes into forebody as narrow tube apparently restricted by bulk of ventral sucker, forms few coils in forebody. Metraterm nearly as long as sinus-sac, enters sinus-sac ventrally to male duct. Eggs small, operculate, with filaments. Vitellarium 2 compact, entire, partly overlapping oval masses, immediately posterior and adjacent to ovary.

Excretory pore terminal. Vesicle obscured by eggs; anterior arms unite dorsally to pharynx.

H o s t : Zosterisessor ophiocephalus (Pallas) (Gobiidae).

L o c a 1 i t y : Off Bourgas, Bulgarian Black Sea coast

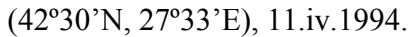

$\mathrm{S}$ i t e : Alimentary canal.

M a t e r i a 1 : BM(NH) 2002.8.16.9-10; CLGE, No. B.26.2.

Remarks. There are few published descriptions of M. skrjabini. Vlasenko (1931) described Derogenoides skrjabini Vlasenko, 1931 apparently on the basis of a single worm from the intestine of Gaidropsarus mediterraneus (as Onos tricirrata) off the Crimean coast of the Black Sea. Skrjabin and Guschanskaya (1955) tentatively retained the species in Derogenoides Nicoll, 1913, suggesting that its position needs further clarification. Naidenova (1969) erected Magnibursatus for this species and redescribed it on the basis of newlycollected material from Gobius niger, G. cobitis, G. paganellus, Neogobius platyrostris, Zosterisessor ophiocephalus, Neogobius cephalarges, G. mediterraneus and Lepidogaster lepidogaster lepidogaster from various localities off the Ukrainian Black Sea coast.

Although adequate, the redescription by Naidenova (1969) provided little morphometric information (see Table 1) that would help in discrimination of new forms. Not surprisingly, Gibson and Køie (1991) encountered difficulties in distinguishing M. caudofilamentosa (Reimer, 1971) Gibson et Køie, 1991 from M. skrjabini when using data taken from the drawing of Naidenova (1969). The size range given by this author, and briefly reiterated by Gaevskaya et al. (1975), is, in our opinion, far too wide to reflect only intraspecific variation (see Table 1). Furthermore, the lower ranges of the measurements are substantially smaller than the upper, and this suggests either some uncertainty concerning the state of development of Naidenova's specimens, or whether the wide range of variation reported by Naidenova (1969) might be due to the description of composite material. In their description of $M$. caudofilamentosa based on mature worms, Gibson and Køie (1991) stated that 'immature worms as small as 350$400 \mu \mathrm{m}$ in length were also found', and these dimensions appear fairly close to the lower range limits (345 $\mu \mathrm{m})$ provided by Naidenova (1969) for mature worms (upper size limit $1,125 \mu \mathrm{m}$ ) (see Table 1 for details). On the other hand, one immature worm in our set of M. skrjabini (Fig. 1B) measured $750 \mu \mathrm{m}$ in length. Overall, our metrical data for M. skrjabini agree well with the upper measurement ranges provided by Naidenova (1969), although indicating a slightly more posterior location of the ventral sucker in the present material (FO/BL 30.5-37.8 vs 27.4\%). This difference, however, might be due to the fact that the comparison comes from a single specimen in the drawing of Naidenova (1969); the ratio is also affected by the allometric growth.

The differentiation of M. skrjabini from M. caudofilamentosa is not clear-cut with respect to morphometric features which tend to show overlapping ranges, although with higher upper limits for all characters in the latter species (Table 1). The ratio FO/BL calculated from the drawing by Gibson and Køie (1991) is smaller, which suggests that the ventral sucker is more anterior in M. caudofilamentosa. However, the values calculated from ranges given in the text fall within the range of $M$. skrjabini (Table 1). Yet, in M. caudofilamentosa the sinus-sac occupies most of the forebody, its muscular wall is thicker (in relation to the space occupied by the seminal vesicle), the ovary is not separated from the posterior testis by uterine coils and the vitelline masses are more elongate. The different hosts and geographical disparity also tend to support their distinct status, as indicated by Gibson and Køie (1991).

\section{Magnibursatus bartolii sp. $\mathrm{n}$. \\ Fig. 2A, B, C}

Description. Based on 10 whole-mounts. Measurements in description from holotype (Fig. 2A), overall ranges given in Table 1. Body elongate, widest at ventral sucker, $1,781 \times 363$. Worms usually take up lateral position when mounted due to strongly muscular, protuberant ventral sucker to form from shallow ' 3 'shape to right-angle (Fig. 2B). Tegument unarmed. Preoral lobe distinct, 29 long. Oral sucker subglobular, subterminal, $146 \times 154$, with 6 papillae on its anterior rim. Ventral sucker substantially larger than oral sucker, $284 \times 325$, sub-spherical, with deep cavity, distinctly protuberant on slight eminence narrower than sucker itself. Sucker-width ratio $1: 2.11$; sucker-length ratio 1 : 1.72. Forebody 734 long $(\mathrm{FO} / \mathrm{BL}=41.2 \%)$. Prepharynx absent. Pharynx subglobular, $79 \times 67$. Two groups of gland-cells present lateral to pharynx or just posterior; associated ducts probably open into pharynx. Oesophagus short. 'Drüsenmagen' present. Caeca end blindly at about level of vitellarium; their course in hindbody is obscured by extensive uterine loops.

Testes 2, oval, smooth, oblique to tandem, very close to each other or contiguous; anterior testis somewhat sinistral, $117 \times 154$, well-separated from ventral sucker by $104(\mathrm{AT} / \mathrm{BL}=5.8 \%)$; posterior testis $175 \times 163$, at 396 from posterior end of body $(\mathrm{PT} / \mathrm{BL}=22.2 \%)$. Seminal vesicle very elongate, c. 75 wide, coiled. Pars 

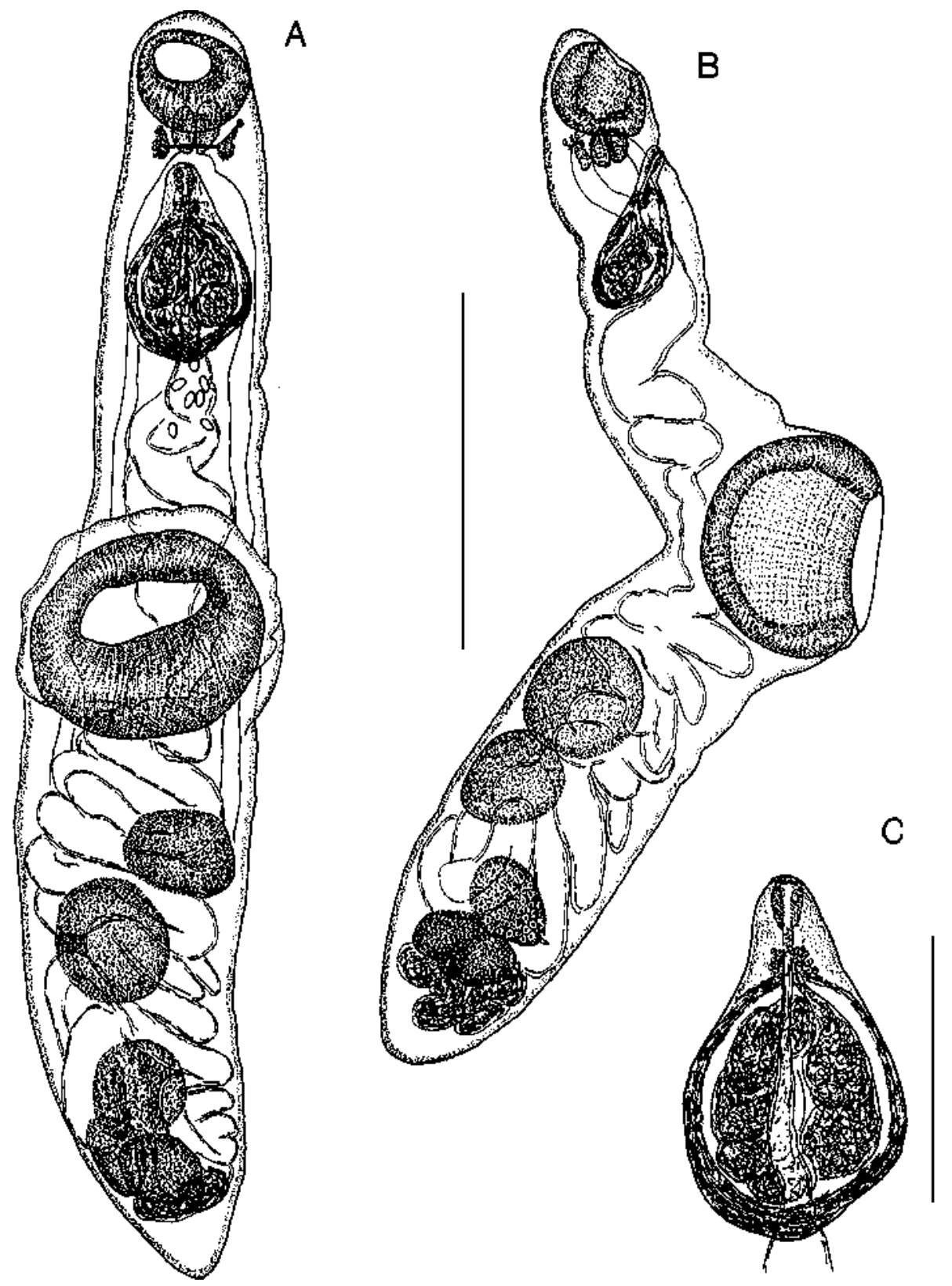

Fig. 2. Magnibursatus bartolii sp. n. ex Boops boops. A - holotype, ventral view; B - paratype, lateral view; C - terminal genitalia. Scale bars: A, B $=500 \mu \mathrm{m} ; \mathrm{C}=200 \mu \mathrm{m}$.

prostatica short, poorly developed. Hermaphroditic duct short. Sinus-sac large, broadly oval, comparable in size to oral sucker, in anterior half of forebody; its posterior 2/3 with multi-layered muscular wall up to $21-30$ thick; length (posterior margin to genital pore) 275, maximum width 179; male and female ducts unite within its proximal thin-walled portion. Genital atrium shallow. Permanent sinus-organ not observed. Genital pore median, just posterior to level of pharynx or more anterior.

Ovary large, subspherical, separated from posterior testis by uterine coils, dorso-medial. Post-ovarian region 213 long, OV/BL 5.8\%. Laurer's canal not seen due to extensive development of uterus but small (?) rudimentary seminal receptacle observed in one specimen. Uterine seminal receptacle well developed; main bulk posterior to vitellarium, filled with spermatozoa and a relatively small number of eggs. Uterus fills much of hindbody, passes into posterior forebody as narrow tube constricted by bulk of ventral sucker, where it again forms numerous coils. Metraterm short, enters sinus-sac ventrally to male duct. Eggs small, 22-25 × 13-14, operculate; filaments or threads present but not readily seen in whole-mounts. Vitellarium in 2 compact, entire, partly overlapping subglobular masses posterior to and 
Table 1. Measurements of Magnibursatus spp. and Tyrrhenia blennii.

\begin{tabular}{|c|c|c|c|c|c|c|}
\hline Species & $\begin{array}{c}\text { Magnibursatus } \\
\text { skrjabini } \\
\text { (Vlasenko, 1931) }\end{array}$ & $\begin{array}{l}\text { Magnibursatus } \\
\text { skrjabini } \\
\text { (Vlasenko, 1931) }\end{array}$ & $\begin{array}{l}\text { Magnibursatus } \\
\text { caudofilamentosa } \\
\text { (Reimer, 1971) }\end{array}$ & $\begin{array}{l}\text { Magnibursatus } \\
\text { bartolii sp. n. }\end{array}$ & $\begin{array}{l}\text { Magnibursatus } \\
\text { minutus sp. n. }\end{array}$ & $\begin{array}{c}\text { Tyrrhenia blennii } \\
\text { Paggi et Orecchia, } 1975\end{array}$ \\
\hline Host & $\begin{array}{l}\text { Gobiidae, Lotidae, } \\
\text { Gobiesocidae }\end{array}$ & $\begin{array}{c}\text { Zosterisessor } \\
\text { ophiocephalus }\end{array}$ & Gasterosteus aculeatus & Boops boops & Neogobius eurycephalus & $\begin{array}{l}\text { Blennius gattorugine, } \\
\text { B. sanguinolentus }\end{array}$ \\
\hline Source & Naidenova (1969) & Present study & Gibson and Køie (1991) & Present study & Present study & Paggi and Orecchia (1975) \\
\hline Body length & $345-1,125$ & $1,163-1,389$ & $1,060-1,420$ & $1,318-1,781$ & $571-826$ & $1,270-2,600$ \\
\hline $\begin{array}{l}\text { Body maximum width } \\
\text { (ventral aspect) }\end{array}$ & $51-375$ & $209-250$ & $295-365$ & 363 & $150-154$ & $250-470$ \\
\hline $\begin{array}{l}\text { Body maximum width } \\
\text { (lateral aspect) }\end{array}$ & - & $192-259$ & - & $250-304$ & $142-192$ & - \\
\hline $\begin{array}{l}\text { Hindbody maximum width } \\
\text { (ventral aspect) }\end{array}$ & - & $209-254$ & $295-365$ & 334 & 150 & - \\
\hline $\begin{array}{l}\text { Hindbody maximum width } \\
\text { (lateral aspect) }\end{array}$ & - & $192-254$ & - & $146-279$ & $133-158$ & - \\
\hline Pre-oral lobe length & - & $13-38$ & up to 30 & $13-29$ & $13-25$ & - \\
\hline Oral sucker length & $47-96$ & $104-113$ & $116-153$ & $100-146$ & $63-75$ & $150-260$ \\
\hline Oral sucker width & $58-124$ & $96-129$ & $124-163$ & $100-154$ & $46-88$ & $140-250$ \\
\hline Pharynx length & - & $46-54$ & $48-67$ & $42-79$ & $25-42$ & $70-100$ \\
\hline Pharynx width & $23-40$ & $50-58$ & $46-64$ & $46-67$ & $25-42$ & $80-140$ \\
\hline Sinus-sac width & - & $104-117$ & $70-140$ & 179 & 75 & $100-130$ \\
\hline Ventral sucker length & - & $175-229$ & $230-305$ & $259-313$ & $104-150$ & $180-250$ \\
\hline Ventral sucker width & 87-202 & $196-213$ & $230-310$ & 325 & 138 & $180-260$ \\
\hline Anterior testis length & $47-164$ & $92-150$ & 70-190 & $88-175$ & $54-92$ & $100-160$ \\
\hline Anterior testis width & $40-124$ & $117-138$ & $100-190$ & 154 & 71 & $130-200$ \\
\hline Posterior testis length & as above & $104-158$ & $60-190$ & $67-175$ & $71-83$ & $100-170$ \\
\hline Posterior testis width & as above & $129-154$ & $95-232$ & 163 & 92 & $140-170$ \\
\hline Ovary length & $31-140$ & $71-88$ & $70-150$ & $50-129$ & $50-63$ & $80-200$ \\
\hline Ovary width & $31-78$ & $92-113$ & $92-152$ & 125 & 63 & $110-160$ \\
\hline Vitellarium 1 length & $28-87$ & $42-96$ & $50-118$ & $58-121$ & $33-63$ & $80-150$ \\
\hline Vitellarium 1 width & $25-62$ & $67-125$ & $74-120$ & $38-75$ & $33-63$ & $70-110$ \\
\hline Vitellarium 2 length & as above & $50-92$ & $70-126$ & $46-96$ & $38-63$ & as above \\
\hline Vitellarium 2 width & as above & $58-92$ & $58-104$ & $42-113$ & $26-63$ & as above \\
\hline
\end{tabular}


Table 1. Continued.

\begin{tabular}{|c|c|c|c|c|c|c|}
\hline Forebody length & - & $354-471$ & $325-475$ & $525-734$ & $188-313$ & - \\
\hline Anterior testis to ventral sucker & - & $0-67$ & - & $92-179$ & $4-21$ & - \\
\hline Post-testicular region & - & $317-396$ & - & $284-396$ & $125-234$ & - \\
\hline Post-ovarian region & - & $175-254$ & - & $154-234$ & $75-154$ & - \\
\hline $\begin{array}{l}\text { Anterior end to centre of ventral } \\
\text { sucker }\end{array}$ & - & $459-584$ & - & $617-880$ & $271-384$ & - \\
\hline $\mathrm{FO} / \mathrm{BL} \%$ & $27.4^{*}$ & $30.5-37.8$ & $\begin{array}{c}26.2^{*} \\
30.7-33.5^{* *}\end{array}$ & $35.9-41.8$ & $27.1-40.1$ & $43.0^{*}$ \\
\hline PT/BL \% & $31.6^{*}$ & $25.8-33.0$ & $29.6^{*}$ & $20.8-24.9$ & $21.9-30.4$ & $23.0^{*}$ \\
\hline $\mathrm{OV} / \mathrm{BL} \%$ & $16.8^{*}$ & $12.6-21.9$ & $22.3^{*}$ & $11.3-14.5$ & $13.1-19.3$ & $15.7^{*}$ \\
\hline AT/BL \% & $2.1 *$ & $0-4.9$ & $0.5^{*}$ & $5.8-10.5$ & $0.5-4.8$ & $14.0^{*}$ \\
\hline VS/BL \% & $34.7^{*}$ & $39.3-45.5$ & $34.5^{*}$ & $43.8-51.1$ & $38.9-47.4$ & $47.2^{*}$ \\
\hline Sucker length ratio & $2.86^{*}$ & $1.68-2.03$ & $\begin{array}{c}2.0^{*} \\
1.98-1.99^{* *}\end{array}$ & $1.95-2.84$ & $1.65-2.26$ & $\begin{array}{c}0.94^{*} \\
0.96-1.20^{* *}\end{array}$ \\
\hline Sucker width ratio & $\begin{array}{c}2.14 * \\
1.50-1.63 * *\end{array}$ & $1.62-2.13$ & $\begin{array}{c}2.15^{*} \\
1.85-2.15\end{array}$ & 2.11 & $1.86-1.94$ & $\begin{array}{c}1.07^{*} \\
1.04-1.29 * *\end{array}$ \\
\hline $\begin{array}{l}\text { Egg length } \\
\text { range } \\
\text { mean } \pm \mathrm{SD} \\
\mathrm{n}\end{array}$ & $25-31$ & $\begin{array}{c}22-28 \\
26 \pm 1.7 \\
60\end{array}$ & $24-30(26-28)$ & $\begin{array}{c}18-26 \\
24 \pm 1.7 \\
75\end{array}$ & $\begin{array}{c}22-30 \\
25 \pm 1.9 \\
34\end{array}$ & $20-25$ \\
\hline $\begin{array}{l}\text { Egg width } \\
\text { range } \\
\text { mean } \pm \mathrm{SD} \\
\mathrm{n}\end{array}$ & $12-16$ & $\begin{array}{c}11-17 \\
13 \pm 1.2 \\
60\end{array}$ & $8-15(10-12)$ & $\begin{array}{c}9-14 \\
12 \pm 1.1 \\
75\end{array}$ & $\begin{array}{c}11-15 \\
13 \pm 1.0 \\
34\end{array}$ & $8-10$ \\
\hline
\end{tabular}

* Calculated from published drawing; $* *$ calculated from range measurements 
contiguous with ovary; anterior $121 \times 71$; posterior $96 \times$ 113.

Excretory pore ventrally subterminal. Vesicle obscured by eggs; arms unite dorsally to pharynx.

Ty pe host:Boops boops (L.) (Sparidae).

L o c a 1 i t i e s : Off Ondárroa, Spain, Bay of Biscay $\left(43^{\circ} 19^{\prime} \mathrm{N}, 2^{\circ} 25^{\prime} \mathrm{W}\right)$ (type locality), 06.vi.2001; and Mal-

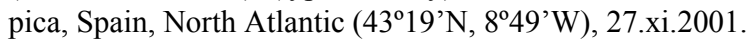

$\mathrm{S}$ i t e s : Branchial chamber and gills.

M a t e r i a 1 : Holotype BM(NH) 2002.8.16.1; paratypes $\mathrm{BM}(\mathrm{NH})$ 2002.16.2-3; paratypes ICBIBE, GMB 5, 8, 21, 23, 24.

E t y m o log y: This species is named for Professor Pierre Bartoli, Centre d'Océanologie de Marseille, in recognition of his major contributions to the taxonomy and ecology of fish digeneans of the Mediterranean region.

Remarks. Magnibursatus bartolii resembles $M$. skrjabini (see above) but has a larger body, larger testes, a larger ovary and a longer forebody. It possesses a distinctly larger sinus-sac, which is located in the anterior half of the forebody, and a substantially larger ventral sucker. The anterior testis is well separated from the ventral sucker by uterine coils (AT/BL 5.8-10.5 vs $0-4.9 \%$ ) (see also Table 1).

This new species differs from $M$. caudofilamentosa (as described by Gibson and Køie 1991) in: the relative width of the space occupied by coils of the seminal vesicle in the ventral plane; the larger proportion of the uterus in the forebody; a larger sinus-sac; and, notably, a longer forebody (FO/BL 35.9-41.8 vs 26.2-33.5\%); more posteriorly located testes (AT/BL 5.8-10.5 vs $0.5 \%$ ) - still separated from the ovary, which is also more posteriorly located (OV/BL 11.3-14.5 vs 22.3\%); and the egg-size [18-26 × 9-14 (mean $24 \times 12)$ vs 24 $30 \times 8-15 \mu \mathrm{m}]$.

But for the number of specimens recovered, the unusual site of the parasite in the branchial cavity might indicate a post-mortem migration from the stomach, as occasionally occurs in the case of individual specimens of the related derogenid Derogenes varicus (Müller, 1784).

This new species is morphologically similar to $M$. minutus sp. $\mathrm{n}$., which is discussed below.

\section{Magnibursatus minutus sp. $\mathrm{n}$.}

Fig. 1C, E

Description. Based on 6 whole-mounts. Measurements in description from holotype; overall ranges given in Table 1 . Body very small, $730 \times 154$, elongate, widest at level of ventral sucker and anterior testis. Tegument smooth. Pre-oral lobe present, 17 long. Oral sucker subterminal, spherical, $75 \times 71$. Ventral sucker muscular, distinctly larger than oral sucker, subglobular, on slight protuberance, $129 \times 138$. Sucker-width ratio 1 : 1.94; sucker-length ratio $1: 1.72$. Forebody 221 long $(\mathrm{FO} / \mathrm{BL}=30.3 \%)$. Prepharynx absent. Pharynx spherical, $33 \times 33$. Oesophagus short. 'Drüsenmagen' present.
Caeca blind, end relatively close to posterior extremity of body.

Testes 2, oval, entire, slightly oblique, relatively close together or contiguous; anterior testis dextral, $54 \times$ 71 , contiguous with posterior border of ventral sucker or slightly posterior to it, at $17(\mathrm{AT} / \mathrm{BL}=2.3 \%)$ from ventral sucker; posterior testis sinistral, $83 \times 92$, in midhindbody, at 200 from posterior extremity of body $(\mathrm{PT} / \mathrm{BL}=27.4 \%)$. Seminal vesicle elongate, tubular, up to 30 wide, coiled. Pars prostatica and hermaphroditic duct short. Sinus-sac $113 \times 75$, broadly oval, comparable in size to oral sucker, occupies most of forebody; its posterior $2 / 3$ with multi-layered muscular wall up to 25 thick; male and female ducts unite within its proximal thin-walled portion. Genital atrium shallow. Permanent sinus-organ not seen. Genital pore median, at level of pharynx.

Ovary sinistral, smaller than testes, oval, adjacent to or apart from posterior testis. Post-ovarian region 117 long $(\mathrm{OV} / \mathrm{BL}=16.0 \%)$. Laurer's canal and rudimentary seminal receptacle not seen. Uterine seminal receptacle well developed, coils between level of ovary and almost posterior extremity of body. Main bulk of uterus in hindbody; few coils in forebody. Metraterm indistinct, enters sinus-sac ventrally. Eggs large in relation to size of body, 24-28 × 13-15, operculate, filamented. Vitellarium 2 compact, almost entirely overlapping, smooth, oval masses, posterior and adjacent to ovary, $63 \times 63$.

Excretory pore terminal. Vesicle obscured by eggs; arms unite postero-dorsally to oral sucker.

$\mathrm{T}$ y $\mathrm{p}$ e $\mathrm{h}$ o s t : Neogobius eurycephalus (Kessler) (Gobiidae).

T y p e 1 o c a 1 i t y : Off Cape Atiya, Bulgarian Black Sea

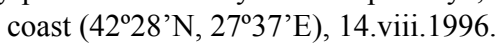

$\mathrm{S}$ i t e : Alimentary canal.

$\mathrm{M}$ a $\mathrm{t}$ e $\mathrm{r}$ i a 1 : Holotype $\mathrm{BM}(\mathrm{NH})$ 2002.8.16.4; paratypes $\mathrm{BM}(\mathrm{NH})$ 2002.8.16.5-8.

Remarks. Magnibursatus minutus differs from $M$. skrjabini (see above), M. caudofilamentosa (as described by Gibson and Køie 1991) and M. bartolii (see above) in its distinctly smaller dimensions (size of body and all organs, see Table 1). We have no doubt about the state of maturity of these worms, since the uterine development is at a stage comparable to the other forms and the hindbody is virtually filled with eggs (see also Fig. 1 for a comparison with an immature specimen of M. skrjabini).

In the position and space occupied by the sinus-sac in the forebody and the relative thickness of its muscular wall (in relation to the width of the space occupied by the seminal vesicle in the ventral plane), M. minutus closely resembles only $M$. caudofilamentosa. These two species are similar also in the presence of a few uterine coils in the forebody, since the sinus-sac leaves little space anterior to the ventral sucker. In addition to the different hosts and localities, M. minutus can be clearly 
differentiated from $M$. caudofilamentosa in the substantially smaller dimensions of the body and all its organs (almost half the size, see Table 1), as well as in its more posteriorly located ventral sucker (VS/BL 38.9-47.4 vs $34.5 \%$ ) (although it could be argued that this is an agerelated feature, as indicated above, our specimens are fully mature).

In addition to distinct size differences, $M$. bartolii has more posteriorly located testes, especially the anterior testis (AT/BL 5.8-10.5 vs 0.5-4.8\%), and smaller eggs. Although ranges for egg length and width tend to overlap (see Table 1), statistical comparison of the egg-size of the three forms described above, revealed significant differences for both length $\left(\mathrm{F}_{2,168}=12.25, \mathrm{p}=0.0000\right)$ and width $\left(\mathrm{F}_{2,168}=16.86, \mathrm{p}=0.0000\right)$ and discriminated the Spanish material as having lower mean values, from the Black Sea specimens (Tukey's comparison of means, $\mathrm{Q}=3.314, \mathrm{p}<0.05)$. Although the two lots from the Black Sea (i.e. M. skrjabini and M. minutus) did not show statistically significant differences in egg-size, the eggs in M. minutus are larger in relation to body size, and this may also serve as a distinguishing feature (see also Fig. $1 \mathrm{C}$ and Key).

\section{DISCUSSION}

The three forms described above share the large muscular ventral sucker, which is located at about midbody and is substantially larger than the oral sucker, as well as the characteristic thick-walled, broadly oval sinus-sac with a long, coiled internal seminal vesicle.

They show similarity with respect to these features, to the halipegine derogenid genus Magnibursatus Naidenova, 1969. Initially, the three forms keyed down to the monotypic genus Tyrrhenia Paggi et Orecchia, 1975 in the key of derogenid genera in Gibson and Bray (1979), the essential feature differentiating Magnibursatus from Tyrrhenia being the presence of numerous filaments or threads at each end of the egg of the former. However, careful observation, allowed us to see filaments on the eggs in whole-mounts, even though, as pointed out by Naidenova (1969) and Gibson and Køie (1991), filaments are readily visible in live specimens but difficult to detect in whole-mounts.

A comparison of the diagnoses of the two genera in Gibson (2002) show that the two genera also differ in the position of the ventral sucker (in the anterior half of the body in Magnibursatus vs near the middle of the body in Tyrrhenia), the shape of the seminal vesicle (coiled, tubular vs saccular, attenuated distally), the presence (in Magnibursatus) or absence (in Tyrrhenia) of a permanent sinus-organ and Juel's organ, and the different extent of the uterus (extends posterior to the vitellarium in Magnibursatus and into the forebody in Tyrrhenia). Although the species described above exhibit somewhat more posterior location of the ventral sucker, and in this tend to resemble Tyrrhenia rather than Magnibursatus, they are close to Magnibursatus in all other morphological aspects.

Nevertheless, we believe that it is also necessary to compare the present species with Tyrrhenia, especially because a worm called 'Tyrrhenia sp.' was listed by Cordero del Campillo et al. (1994; quoted from thesis of Pellicer Carrasco 1992) from Sarpa [as Boops] salpa off the Mediterranean coast of Spain [although not reported by López-Román and Guevar-Pozo (1971) in a survey of this host in the same region]. The type and only species of the genus, T. blennii Paggi et Orecchia, 1975 (as described by Paggi and Orecchia 1975), differs from all three forms described above in having both suckers of a similar size; a sinus-sac which is claviform, thinwalled and rather small in relation to the size of the oral sucker; and an anterior testis well posterior to the ventral sucker. Other differences, relating to individual species of Magnibursatus, are as follows (see also Table 1):

- Magnibursatus skrjabini differs from T. blennii in: the smaller dimensions of the body, oral sucker, pharynx, testes and ovary; the larger sucker-ratios (width 1 : 1.62-2.13 vs $1: 1.07$; length $1: 1.68-2.03$ vs $1: 0.94)$; the shorter forebody (FO/BL 30.5-37.8 vs 43.0\%); and the testes being more anteriorly located in the hindbody (AT/BL $0-4.9$ vs $14.0 \%$ and $\mathrm{PT} / \mathrm{BL} 25.8-33.0$ vs $23.0 \%)$

- In M. bartolii the sinus-sac is larger, broadly oval, comparable in size to the oral sucker and possesses a thick muscular wall; the ventral sucker is strongly muscular, much larger and about twice the size of the oral sucker (for type specimens, sucker-width ratio 1 : 2.11 vs $1: 1.07$ in $T$. blennii; sucker-length ratio 1 : 1.72 vs $1: 0.94)$; and the anterior testis is not as distant from the ventral sucker (AT/BL 5.8-10.5 vs 14.0\%).

- As compared to M. minutus, T. blennii has a relatively longer forebody and a more posteriorly located anterior testis (AT/BL 14.0 vs $0.5-4.8 \%$ ), a claviform sinus-sac which occupies a small proportion of the forebody, a smaller sucker-ratio and somewhat smaller eggs $(20-25 \times 8-10$ vs 22-30 × 11-15 $\mu \mathrm{m})$.

Our study suggests that Magnibursatus may have a wider distribution and greater range of host species than was supposed. As far as we are aware, the only record of a derogenid in B. boops refers to specimens listed as Derogenes varicus (Müller, 1784), reported from samples taken at the Gulf of Lyons and Tunisian coasts (Cook et al. 1981, Anato et al. 1991, Renaud et al. 1980). The historical biogeography of fish halipegines related to Magnibursatus, such as Arnola Strand, 1942, was commented upon by Gibson and Bray (1979), who suggested a link with the ancient Sarmatic Sea of Central Asia. This and a link with the Tethys Sea was developed in more detail by Gibson and Køie (1991). However, the latter authors found that Magnibursatus was a bit of an anomaly, with a disjunctive distribution - the Black Sea and eastern Danish / western Baltic waters. As the present finding of a species of this genus 
off the Atlantic coast of Spain is approximately halfway between these localities, it makes the northerly records look less extreme and supports Gibson and Køie's suggestion regarding the northerly movement of the fauna along the Atlantic coast of Europe after the last ice-age.

More extensive sampling and possibly molecular evidence would be useful in assessing the status of the new forms described above. Considering their distinct species status, which we have endorsed here, we subscribe to the poetic metaphor of the late Dr. A.A. Shigin, that "if not described, such forms would remain unnoticed, pale animal shadows", thus drawing attention to this little-known group.

In order to help distinguish the four species of Magnibursatus, a key is presented below.

\section{Key to the species of Magnibursatus}

1 Sinus-sac large (length $>250 \mu \mathrm{m}$, width $>150$ $\mu \mathrm{m})$. Anterior testis well apart from ventral sucker $(\mathrm{AT} / \mathrm{BL}>5 \%)$...................... . bartolii $\mathrm{sp} . \mathrm{n}$.

(Host: Boops boops)

- Sinus-sac smaller (length $<250 \mu \mathrm{m}$, width $<150$ $\mu \mathrm{m})$. Anterior testis contiguous with posterior border of ventral sucker or slightly posterior $(\mathrm{AT} / \mathrm{BL}<5 \%)$
2 Sinus-sac/forebody length ratio $1:<2$. Muscular wall of sinus-sac thick (width $1 / 2-1 / 4$ of width of space occupied by seminal vesicle) .............. 3

- Sinus-sac/forebody length ratio $1:>2$. Wall of sinus-sac relatively thin (width $1 / 6$ of width of space occupied by seminal vesicle) ... M. skrjabini

(Hosts: gobiids)

3 Body very small (length $<1,000 \mu \mathrm{m}$, width $<200$ $\mu \mathrm{m})$; oral sucker dimensions $<100 \mu \mathrm{m}$; ventral sucker dimensions $<150 \mu \mathrm{m}$. Eggs large in relation to body size (length c. $3.5-4 \%$ of body length) M. minutus sp. $\mathrm{n}$.

(Host: Neogobius eurycephalus)

- Body large (length $>1,000 \mu \mathrm{m}$, width $>200 \mu \mathrm{m}$ ); oral sucker dimensions $>100 \mu \mathrm{m}$; ventral sucker dimensions $>200 \mu \mathrm{m}$. Eggs smaller in relation to body size (length c. 2.0-2.5\% of body length) M. caudofilamentosa

(Host: Gasterosteus aculeatus)

Acknowledgements. This work was supported by grants GV01-9 (OCYT), BOS2002-878 (MCYT of Spain), CACSA, EC Marie Curie Fellowship to AMP (HPMD-CT2000-00037), and a visiting research fellowship from MECD of Spain to AK (SB2000-0246). MF benefits from a "Ramón y Cajal" contract from MCYT of Spain. We thank the referees for their useful comments.

\section{REFERENCES}

ANATO C.B., KTARI M.H., DOSSOU C. 1991: La parasitofaune métazoaire de Boops boops (Linné, 1758), poisson téléostéen Sparidae des côtes tunisiennes. Oebalia 17: 259-266.

COOK J.-M., BLANC G., ESCOUBET P. 1981: Parasites et poissons d'aquariums méditerranéens. Vie Marine 3: 139144.

CORDERO del CAMPILLO M., ORDOÑEZ L.C., FEO A.R. 1994: Indice-Catálogo de Zooparásitos Ibéricos. Universidad de León, León, 650 pp.

GAEVSKAYA A.V. et al. (Eds.) 1975: [Keys to the parasites of vertebrates of Black and Azov Seas. Parasitic invertebrates of fishes, fish-eating birds and marine mammals.] Naukova Dumka, Kiev, 551 pp. (In Russian.)

GEORGIEV B.B., BISERKOV V.Y., GENOV T. 1986: In toto staining method for cestodes in iron acetocarmine. Helminthologia 23: 279-281.

GIBSON, D.I. 2002: Family Derogenidae Nicoll, 1910. In: D.I. Gibson, A. Jones and R.A. Bray (Eds.), Keys to the Trematoda. Vol. 1. CAB International, Wallingford, pp. 351-368.

GIBSON D.I., BRAY R.A. 1979: The Hemiuroidea: terminology, systematics and evolution. Bull. Br. Mus. (Nat. Hist.) Zool. 36: 35-146.

GIBSON D.I., KØIE M. 1991: Magnibursatus caudofilamentosa (Reimer, 1971) n. comb. (Digenea: Derogenidae) from the stickleback Gasterosteus aculeatus in
Danish waters: a zoogeographical anomaly? Syst. Parasitol. 20: 221-228.

LÓPEZ-ROMÁN R., GUEVAR-POZO D. 1971: Parasite fauna of fish from Mediterranean coast of Granada (Spain). Intestinal digenea of Boops salpa (L.). Proc. Second Int. Congr. Parasitol., Washington, 6-12 September, 1970. J. Parasitol. 56: 216.

NAIDENOVA N.N. 1969: [Erection of a new trematode genus, Magnibursatus nov. gen. (Hemiurata: Halipegidae), from Black Sea fishes.] Materialy Nauchnoy Konferentsii Vsesoyuznogo Obshchestva Gel'mintologov 1: 187-195. (In Russian.)

PAGGI L., ORECCHIA P. 1975: Tyrrhenia blennii g.n. sp.n. (Hemiurata: Halipegidae Poche, 1925) parassita di Blennius gattorugine e Blennius sanguinolentus. Parassitologia 17: 57-64.

RENAUD F., ROMESTAND B., TRILLES J.-P. 1980: Faunistique et écologie des métazoaires parasites de Boops boops Linnaeus, 1758 (Téléostéen Sparidae) dans le Golfe du Lion. Ann. Parasitol. Hum. Comp. 55: 467-476.

SKRJABIN K.I., GUSCHANSKAYA L.K. 1955: [Suborder Hemiurata (Markevitsch, 1951) Skrjabin et Guschanskaya, 1954. Second part.]. Osnovy Trematodologii 11: 613-615 (In Russian.)

VLASENKO P.V. 1931: [On the parasitic worm fauna of fishes of the Black Sea.] Trudy Karadagskoy Biologichnoy Stantsii Imeni T.I. Vyazemskogo 4: 88-136. (In Russian.)

Accepted 20 March 2003 